\title{
THE RELATIONSHIP BETWEEN NUMBERS OF INTERNATIONAL TOURIST ARRIVALS AND ECONOMIC GROWTH IN THE ASEAN-8: PANEL DATA APPROACH
}

\begin{abstract}
Garnis Nur Anggraeni*1
${ }^{1}$ Faculty of Economic and Business, Universitas Airlangga, Indonesia es that identified as the determinant of international tourist arr pectancy. Furthermore, the number of international tourist arrivals have a significant effect on economic growth in conform with tourism-led economic growth hypothesis (TLGH). This finding infers that tourism sector could be developed as an effort to increase economic growth.
\end{abstract}

\author{
ARTICLE INFO \\ Received: March $24^{\text {th }}, 2017$ \\ Revised: May $4^{\text {th }}, 2017$ \\ Accepted: May $19^{\text {th }}, 2017$ \\ Online: June $20^{\text {th }}, 2017$ \\ *Correspondence: \\ Garnis Nur Anggraeni \\ E-mail: \\ wennyrestika75@gmail.com
}

Keywords: International Tourism, Economic Growth, International Tourist Arrivals, TLGH, Panel Data

JEL : Z30, F43, C23

To cite this document: Anggraeni, G.N. (2017). The Relationship Between Numbers of International Tourist Arrivals and Economic Growth in The Asean-8: Panel Data Approach. JDE (Journal of Developing Economies), 2(1), 38-46.

\section{Introduction}

Tourism has become one of the important sectors in international trade, and at the same time is a source of the main foreign exchange earnings for many country. Tourism's contribution to the growth of economy can be seen through exports. According to UN Steering Committee on Tourism for Development (2013), tourism representing 30\% of world services exports and 5\% against global direct GDP. Case these include the reason why the sector tourism became one strategy-oriented economic growth export.

Tourism is a labor-intensive industry, who have contributed big enough for employment (World Travel \& Tourism Council , 2012). As a sector covering a wide range of industry interrelated, tourism has the capacity to stimulate trade $d$ an economic growth. Especially more emphasis on the characteristics of the tourism the beauty of the natural environment and cultural heritage is a comparative advantage for developing country (United Nations World Tourism Organization, 2013).

However, despite the increasing role and popularity of tourism, the topic have received little attention in the literature Economy. Existing studies generally examine the contribution of the agricultural sector and manufacture on exports, compared to the service sector of the

JDE (Journal of Developing Economies) p-ISSN: 2541-1012; e-ISSN: 2528-2018 
economy. Among the few literatures that focus on the services sector, and more specifically in the tourism sector, mostly emphasis on estimation and forecasting tourism demand and income formation through the process multiplier (Kareem, 2013).

In the economic literature, the ability of tourism to support growth economists calls tourism-led growth hypothesis (TLGH) (Samimi et al., 2011). This hypothesis states that tourisminternational is a strategic factor that the potential for economic growth. According Panagiotidis et al. (2012), TLGH that derived directly from export-led growth hypothesis (ELGH). In ELGH stated that economic growth can produced not only through an increase in the amount of labor and capital in the economy, but also can obtained by increasing exports (Balassa, 1978). Tourist expenditure, which is an alternative form of exports, can a source of foreign exchange earnings for the destination country.

TLGH analyze the possible relationship between tourism and economic growth. Theoretically there is a debate of the relationship between tourism development and economic growth. Be how many existing studies generally carried out to determine the direction of the relationship between per economic growth and tourism. Kim et al. (2006) found that twoway causality between a growth and development of tourism in Taiwan. Instead, Katircioglu (2009) did not find the causal relationship between the internal tourism and economic growth in the national Program Turkey. In Chile, Brida et al. (2009) obtained one-way relationship from tourism international economic while Oh (2005) found hypothesis tourism-led economic growth does not apply in Korea. In his research, instead obtain their implications tourism-led economic expansion in South Korea.

However, according to Du \& Ng (2011) there are possibilities two weaknesses methodology in previous studies. First, this usual mainstream approach used in the form of econometric test, Especially if the study does not control the standard determinant of growth, such as technology, human capital, and institutions/institutions. Can The estimates obtained are biased due to omitted variable problems. Second, previous studies generally focus on only one country only, so there is considerable doubt whether the results of the study were found to have an implication general.

Therefore, to anticipate problems, this research will includes eight ASEAN member countries with a view to test the effect of owned international tourism to per economic growth and decisive determinant of international tourism. tourism Indicators is the amount of travel used tourist arrivals (international tourist arrivals). this indicator shows the number of foreign tourists who travelling into a tourist destination. Eighth ASEAN countries include Indonesia, Malaysia, Singapore, Philippines, Thailand, Vietnam, Cambodia, and Laos. at researcher This late Brunei Darussalam and Myanmar is not included in the object of study Preferably unavailability of data.

According to Eugenio-Martín et al. (2004), there are three aspects that are theoretically effect on the development of tourism, namely: Infrastructure, education, and security. Infrastructure development is an element that vital for all projects tourism. In this aspect include the availability of water, electricity, telephone, and facilities transportation such as roads or transport systems public. Next is the aspect education, is a necessary condition for local residents to get potential jobs in tourism activities. On general tourism activities requires knowledge in various fields, such as communication (language), food service, hospitality, transportation and, management expertise. Also, there are security aspects as excellence in vacation place. Most tourists are looking for comfortable and no problem. With other words, it can be assumed that most of the travel wan prefer to avoid the risk (risk aversion). Security or in other words political stability can be attributed to the GDP and how GDP is distributed in a country.

Analysis of tourism determinant done by using one namely tourism indicators international tourism arrivals as the dependent variable. The independent variables used include 
GDP per capita as a proxy for growth economic, Gross Fixed Capital Formation (GFCF) as a proxy of the capital, government expenditure on education, secondary school gross enrollment ratio and tertiary school gross enrollment ratio, life expectancy as a proxy of capital as well as drain, and the level of prices and international trade as proxy of the price.

Analysis of the influence of tourism on the growth of economy do by focusing on economic growth proxy such as GDP per capita as the dependent variables. The independent variables were used among others international tourist arrivals which is an indicator of tourism, Gross Capital Formation, government expenditure on education and general government final consumption expenditure as part of the economic variables and indices stabilities political and index control of corruption as part of the variable social.

Research to find the relationship between tourism international and economic growth hasa lot to do. However there still has been no study the determinants of international tourism in ASEAN-8 region and influence international tourism indicators against economy growth. based on some findings in previous research, this study attempts to further analyze related determinants of international tourism and relationship between international tourism with economic growth in ASEAN-8 period 2000- 2012.

\section{Literature Review}

Sector development indicators tourism industry can be measured through international tourist arrivals (the number of foreign tourist arrivals), long provision of furniture, and the amount of tourist expenditure (Theobald, 2005), The greater it is amount tourist arrivals and length of stay of tourists in destination countries must be increase tourist spending tourism products. The higher it is Traveler expenditures for goods and services on the destination countrywill certainly push local economic growth.

In the context of the theory of supply and demand theory of tourism, then the number visits and tourist spending are included in the side demand (Tribe, 2004). The amount of tourism sector opportunities in encouraging economic growth led to a lot of countries complete in develop tourism, with increasing the tourism competitiveness, to bring in foreign exchange. Withthe increase in power tourism competitiveness is expected to be can boost the performance of thetourism sector, which is shown with the increase in the number of tourist arrivals, length of stay, and tourist spending.

As a concept put forward the concept of competitiveness and sustainability tourism proposed by Ritchie \& Crouch (2003), in this study tourism performance indicators measured with international tourist arrivals (amount foreign tourist visits) were treated as the dependent variable (dependent variable), Furthermore, human capital variables and variables other economic, which can be regarded as a dimension of excellence comparative treated as independent variables (independent variables), Human capital variables consist of age expectancy life (health indicators), secondary school gross enrollment ratio (A quality indicator HR), and tertiary school gross enrollment ratio (Indicator of the quality of human resources). Variables Other economic consist of Government Fixed Capital Formation (describing infrastructure development), the price level (describe tourist attraction), Government expenditure on education (Describing human capital investment), and international trade (export and import al sector).

Travelers are usually asked for four kinds of goods The country's main services travel destinations, i.e. accommodation, food, facility as transportation and entertainment services (Eugenio-Martín et al., 2004). In most developing countries, for me filled the This request then current production levels necessary increased. This gives two positive effects on the economy, namely increased production and income, and increased employment due to the tourism sector is labor intensive (labor intensive). Thus, the tourism sector can contribute significantly to economic growth. 
Economic growth theory explain the factors which determine economic growth and how linkages between those factors that a process of growth. According Petrakos et al. (2007), amongthe existing theories can be divided into two main theories: theory and newer neoclassical theory endogenous growth. Neoclassical theory is based on model growth Solow rather refersto the accumulation of capital and labor in generating output, with advances in technology as an exogenous factor. While the endogenous growth theory developed by Romer and Lucas is concerned with human capital and innovation capacity, with technological advances as an endogenous factor. Emphasizes endogenous growth theory in institutions, legal system and political, social and cultural factors, demographics, and geographic. In addition there are other theories also highlight the important role of non-economic as factors that contribute to the performance economy. As stated in The Global Competitiveness Report, the sub-index of basic needs include institutions (i.e. excluding index political stability as well as the index of corruption control), and the economic environment (i.e. including general government final consumption, gross capital formation, as well as government expenditure on education), The tourism sector is a part of overall economic productivity so variable foreign tourism as consuming goods and services has a relationship with economic growth (GDP).

The hypothesis can be drawn from this study it was suspected of GDP per capita, Gross Fixed Capital Formation (GFCF), the price level, government expenditure on education, secondary school gross enrollment ratio and tertiary gross school enrollment ratio, life expectancy, as well as international trade significant effect partial to international tourist arrivals per capita ASEAN-8 in the period 2000-2012. Additionally, allegedly international tourist arrivals per capita, Gross Capital Formation (GCF), Government expenditure on education, general government final consumption expenditure (GGFCE), the political stability index, and the index of the corruption control significant effect partially to GDP per capita in ASEAN-8 period 2000-2012.

\section{Research Methods}

The model used in this study refers to $p$ No studies conducted by Eugenio-Martín et al. (2004). The first equation to be estimated are as follows:

$$
\begin{gathered}
\text { ITApc }_{i t}=\beta_{0}+\beta_{1} \text { GFCF }_{i t}+\beta_{2} \text { GDPpcd }_{i t}+\beta_{3} \text { PRICE }_{i t}+\beta_{4} \text { GOVED }_{i t}+\beta_{5} \text { EDUsec }_{i t}+\beta_{6} \\
\text { EDUter }_{i t}+\beta_{7} \text { LIFE }_{i t}+\beta_{8}{ }^{\prime \prime} \text { TRADE }_{i t}+\mu_{i t}
\end{gathered}
$$

Next, the second equation to be estimated se how its done by Eugenio-Martín et al. (2004) are as follows:

$$
\begin{gathered}
\mathrm{GDPpc}_{\mathrm{it}}=\beta_{0}+\beta_{1} \mathrm{ITApc}_{\mathrm{it}}+\beta_{2} \mathrm{GCF}_{\mathrm{it}}+\beta_{3} \mathrm{GOVED}_{\mathrm{it}}+\beta_{4} \mathrm{GGFCE}_{\mathrm{it}}+\beta_{5} \mathrm{STAB}_{\mathrm{it}} \\
+\beta_{6} \mathrm{CORP}_{\mathrm{it}}+\mu_{\mathrm{it}}
\end{gathered}
$$

Some of the variables used in equation (1) among others ITApc that defined as international tourist arrivals per capita, GFCF i.e. Gross Fixed Capital Formation, GDPpc namely gross domestic product per capita KONS tan top year basis in 2005, PRICE is ringkat price, ie GOVED Government expenditure on education, EDUsec namely secondary school gross enrollment ratio, Namely EDUter tertiary school gross enrollment ratio, LIFE namely life expectancy, TRADE international trade. Some of the variables used in equation (2) among others GDPpC namely gross domestic product per capita constant over the base year of 2005, ITApc defined as international tourist arrivals per capita, GCF is Gross Capital Formation, GOVED namely Government expenditure on education, GGFCE that is General Government Final Consumption Expenditure, STAB that the stability index political, and CORP namely corruption control index.

The approach used in this study is quantitative approach conducted using panel data regression, which is combination of the data time series (2000-2012) and data cross-section (ASEAN-8, including Indonesia, Malaysia, Singapore, the Philippines, Thailand, Vietnam, Cam- 
bodia, and Laos).

\section{Results and Discussion}

Panel data regression methods can be estimated using three models: Pooled Least Square (PLS), Fixed Effect Model (FEM), and Random Effect Model (REM). To choose these models should be in do testing models. There three tests conducted on the research models this. First, the Chow test-test PLS is used to select the model or FEM. Table 1 shows the value prob> F (FEM) model 1 at 0.0000 which means smaller of $\alpha(0.1)$ so that $H_{0}$ rejected and $H_{1}$ accepted, it means a more precise estimation model used in model 1 for while is FEM.

Second, test the Breusch-Pagan LM test was used as statistical considerations to choose PLS model or REM. Seen in Table 1 that prob> chi2 model 1 amounted to 1.0000 is greater than $\alpha(0.1)$, then the conclusion $\mathrm{H} 0$ received and $\mathrm{H} 1$ rejected so that a more precise estimation models in use in model 1 for while is PLS. Third, the Hausman test performed to choose a model FEM or REM. In Table 1 values obtained prob>chi2 model 1 at 0.0000 with $\alpha$ $(0,1)$ then the value prob>chi2 smaller than $\alpha$, so that $H_{0}$ rejected and $H_{1}$ be accepted. Therefore the estimation model is most appropriate to be used in model 1 is FEM.

Table 1: Results of Testing Model 1

\begin{tabular}{lll}
\hline \multicolumn{1}{c}{ Kind of Test } & \multicolumn{1}{c}{ Hypothesis } & \multicolumn{1}{c}{ Probability } \\
\hline Chow-test & $\mathrm{H} 0:$ PLS & Prob $>\mathrm{F}(\mathrm{FEM})$ \\
\cline { 2 - 3 } & $\mathrm{H} 1: \mathrm{FEM}$ & $0,0000^{*}$ \\
\hline Bp-LM test & $\mathrm{H} 0:$ PLS & Prob $>$ Chi2 \\
\cline { 2 - 3 } & $\mathrm{H} 1:$ REM & 1,0000 \\
\hline Hausman test & $\mathrm{H} 0:$ REM & Prob $>$ Chi2 \\
\cline { 2 - 3 } & $\mathrm{H} 1:$ FEM & $0,0000^{*}$ \\
\hline Number of observation : 104 & \\
\hline Cross section:13 & \\
\hline Significance 0.1 & \\
\hline
\end{tabular}

Next steps The same was done for determine estimation model 2. The best model CHOW- Results test Table 2 shows the value prob> F (FEM) model 2 at 0.0000 which is smaller than $\alpha(0.1)$. In other words, $\mathrm{H}_{0}$ rejected and $\mathrm{H}_{1}$ received so precise estimation models used in model 2 is temporarily FEM.

Table 2: Results of Testing Model 1

\begin{tabular}{lll}
\hline Kind of Test & Hypothesis & Probability \\
\hline Chow-test & $\mathrm{H}_{0}:$ PLS & Prob $>\mathrm{F}(\mathrm{FEM})$ \\
\cline { 2 - 3 } & $\mathrm{H}_{1}:$ FEM & $0,0000^{*}$ \\
\hline Bp-LM test & $\mathrm{H}_{0}:$ PLS & Prob $>$ Chi2 \\
\cline { 2 - 3 } & $\mathrm{H}_{1}:$ REM & $0,0000^{*}$ \\
\hline Hausman test & $\mathrm{H}_{0}:$ REM & Prob $>$ Chi2 \\
\cline { 2 - 3 } & $\mathrm{H}_{1}:$ FEM & $0,0002^{*}$ \\
\hline Number of observation : 104 & \\
\hline Cross section : 13 & & \\
\hline *Significance 0.1 & \\
\hline
\end{tabular}

Then the results of BP-LM test model 2 in Table 2 are known to have a value prob > chi2 of 0.0000 . This value is smaller than $\alpha(0.1)$ which means that $H_{0}$ rejected and $H_{1}$ accepted 
that the estimated model in model 2 for while is PLS. last of testing with Hausman test for model 2 are as in Table 2 shows that the value prob> chi2 of 0.0002 . with $\alpha(0.1)$ then the value prob> chi2 smaller than $\alpha$, so that $\mathrm{H}_{0}$ rejected and $\mathrm{H}_{1}$ be accepted. Therefore, the model estimates the most appropriate for use in model 2 is FEM.

Based on the conclusions from the results of testing the model, then the best estimate models used in this study to model $1 \mathrm{~d} 2$ is an FEM models. Remember used panel data have data cross-section in large numbers, then model 1 and model 2 suspected of having problems Heteroscedasticity. Use of the method the weighted to minimize heteroscedasticity in the model estimated. Improvements to the problems in the classical assumption can be overcome by FEM with the weighted estimation method and within group estimator, who also correcting the problems of autocorrelation level one (AR 1) (Baltagi, 2011). Here are the results rocessing FEM model 1 using an estimate of the and the weighted method within group estimator.

Table 3: Estimates of Fixed Effect Model (FEM) with the Weighted Method and Within Group Estimator Model 1

\begin{tabular}{lcccl}
\hline Variable (Dependent: ITApc) & Coef & Std.Error & t-stat & Prob \\
\hline Constanta & -2.159541 & 0.421406 & -5.12 & 0.000 \\
\hline Gross fixed capital F (GFCF) & 0.001203 & 0.002695 & 0.45 & 0.657 \\
\hline GDP per Capita & 0.000065 & $9.59 \mathrm{e}-06$ & 6.80 & 0.000 \\
\hline Price level & 0.001702 & 0.002628 & 0.65 & 0.519 \\
\hline Gov. expend. On. Educ. (GOVED) & -0.009252 & 0.012849 & -0.72 & 0.474 \\
\hline Secondary Enrollment (EDUsec) & -0.003379 & 0.001918 & -1.76 & 0.082 \\
\hline Tertiary enrollment (EDUter) & -0.000734 & 0.003023 & -0.24 & 0.809 \\
\hline Life expectancy & 0.033102 & 0.013907 & 2.38 & 0.020 \\
\hline International trade & 0.000023 & 0.000462 & 0.05 & 0.961 \\
\hline & & & & \\
\hline R-SQUARE : 0.6135 & (F-statistics): 0.0000 & Total Observation : 104 \\
\hline
\end{tabular}

Next is the result of processing using e stimasi FEM methods weighted and within groupestimator in model 2.

Table 4: Estimation Results Fixed Effects Model (FEM) with the Weighted Method and Within Group Estimator Model 2

\begin{tabular}{lllll}
\hline Variable (Dependent: GDPpc) & Coef & Std.Error & t-stat & Prob \\
\hline Constanta & 6321.562 & 104.0375 & 60.76 & 0.000 \\
\hline Inter.tourist arrivals (ITApc) & 4767.97 & 649.12 & 7.35 & 0.000 \\
\hline Gross Capital Formation (GCF) & -4.790865 & 16.26089 & -0.29 & 0.769 \\
\hline Gov. expend. on. educ.(GOVED) & 32.2014 & 94.74885 & 0.34 & 0.735 \\
\hline Gov. Final Consump. (GGFCE) & -134.2274 & 77.59024 & -1.73 & 0.087 \\
\hline Stability Politics (STAB_RANK) & -11.08385 & 7.709704 & -1.44 & 0.154 \\
\hline Control of corruption(CORP_RANK) & 2.369625 & 10.55623 & 0.22 & 0.823 \\
\hline & & & & \\
\hline R-SQUARE : 0.6135 & (F-statistics): 0.0000 & Total Observation: 104 \\
\hline
\end{tabular}

The results of the panel data regression to model 1 in Table 3 show that GDP per capita has an influence on international tourist arrivals per capita, research result by Kareem and Idowu (2013), Culiuc (2014), and Eilat \& Einav (2004) in line with the results of this study that the price level and international trade is a significant factor in modeling international tourist arrivals. Table 3 indicates that economic growth has a positive impact on tourism develop- 
ment. This is indicated by increase in GDP per capita reflects the market potential and the amount of resourceshuman and capital of a nation, which is increasingly attracting foreign tourists countries to come to the country. The results of this study are in accordance theory by Culiuc (2014) Using data of the European Economic Community (OECD) which finds that GDP is a factor that influences the number of foreign tourist arrivals significantly.

The next panel data regression results for model 2 on Table 4 shows that international tourist arrivals per capita effect on economic growth (GDP per capita). This is consistent with the finding from Eugenio-Martín et al. (2004) using data from panel of nations Latin America in 1985-1998 found that there was a positive relationship between economic growth and the number of foreign tourist arrivals. Further research by Dritsakis (2011) by clicking use eight data panel European countries also showed a positive between the number of arrivals foreign tourists with economic growth. Meanwhile, research Gökovali \& Bahar (2006), using data panel of countries Mediterranean from years 1987-2002, also found a positive contribution to the number of tourist arrivals to economic growth. From this study we can be said that the contribution of industry tourism plays a role important in promoting economic growth in $A$ SEAN-8.

\section{Conclusion}

Based on the estimation, economic growth namely GDP per capita, secondary school grossenrollment ratio And age of hope life, has a significant influence partially to the number of arrivals foreign tourists per capita. Additionally, Indicator international tourism the form international tourist arrivals per capita or tourist arrivals per capita and other economic variables in the form of General Government Final Consumption Expenditure (GGFCE) has a significant influence partially to the economic growth indicators, namely GDP per capita. This matter in accordance with the tourism-led growth hypothesis (TLGH). Based on the findings in above it can be stated that there is a relationship both directions between tourism international and economic growth, which is between international tourist arrivals per capita and GDP per capita in ASEAN-8.

\section{References}

Andriotis, K. (2002). Scale of hospitality firms and local economic development - evidence fromCrete. Tourism Management , 4 (23), 333-341.

Anggraeni, G. N. (2016). Hubungan antara Faktor-Faktor Pariwisata dan Pertumbuhan Ekonomidi ASEAN-8: Pendekatan Data Panel. Surabaya: FEB-UNAIR.

Balassa, B. (1978). Exports and Economic Growth: Further Evidence. Journal of Development Economics , 5 (2), 181-189.

Baltagi, B. H. (2011). Econometrics (5th ed.). New York: Springer.

Blake, A., Sinclair, M. T., \& Soria, J. A. (2006). Tourism Productivity: Evidence from theUnited Kingdom. Annals of Tourism Research , 33 (4), 1099-1120.

Blanke, J., \& Chiesa, T. (2013). The Travel \& Tourism Competitiveness Report 2013. Geneva: World Economic Forum.

Boediono. (1999). Seri Sinopsis Pengantar Ilmu Ekonomi No.4 : Teori Pertumbuhan Ekonomi. Yogyakarta: BPFE-UGM.

Brida, J. G., \& Pulina, M. (2010). A Literature Review on The Tourism-Led Growth Hypothesis. Italia: Centre for North South Economic Research (CRENoS).

Brida, J. G., Risso, W. A., \& Bonapace, A. (2009). The Contribution of Tourism to Economic Growth: An Empirical Analysis for the Case of Chile. European Journal of Tourism Research , 2 (2), 178-185. 
Culiuc, A. (2014). Determinants of International Tourism. IMF Working Paper, 14 (82). Dritsakis, N. (2011). Tourism Development And Economic Growth In Seven Mediterranean Countries: A Panel Data Approach.

Dritsakis, N. (2011). Tourism development and economic growth in seven Mediterranean countries: A panel data approach. Tourism Economics, 18(4), 801-816.

Du, D., \& Ng, P. (2011). Is Tourism a Long-run Economic Growth Factor? The W. A. Franke College of Business. Arizona: Northern Arizona University.

Eilat, Y., \& Einav, L. (2004). The Determinants of International Tourism: A Three- Dimensional Panel Data Analysis. Applied Economics (36), 1315-1327.

Eugenio-Martín, J. L., Morales, N. M., \& Scarpa, R. (2004). Tourism and Economic Growth in Latin American Countries: A Panel Data Approach. Nota Di Lavoro,26.

Goeldner, C. R., \& Ritchie, J. R. (2012). Tourism: Principles, Practices, and Philosophies (12th Edition ed.). Hoboken, New Jersey, United States of America: John Wiley \& Sons, Inc.

Gökovali, U., \& Bahar, O. (2006). Contribution of Tourism to Economic Growth: A Panel Data Approach. Anatolia: An International Journal of Tourism and Hospitality Research , 17 (2).

Gujarati, D. N. (2003). Basic Econometrics (4th ed.). New York: McGraw-Hill Companies, Inc.

Hall, C. M. (2008). Tourism Planning : Policies, Processes and Relationships (2 ${ }^{\text {nd }}$ Edition ed.). Harlow, England: Pearson Prentice Hall.

Hall, C. M., \& Page, S. J. (2006). The Geography of Tourism \& Recreation (3rd ed.). New York: Routledge.

Holloway, J. C., Humphreys, C., \& Davidson, R. (2009). The Business of Tourism ( ${ }^{\text {th }}$ ed.). United Kingdom: Prentice Hall.

Ibrahim, M. A. (2011). The Determinants of International Tourism Demand for Egypt: Panel Data Evidence. European Journal of Economics, Finance, and Administrative Sciences (30), 50-58.

Kareem, O. I. (2013). A Reassessment of Tourism-Exports Led Growth Hypothesis in Africa. American Journal of Tourism Research , 2 (1), 130-140.

Katircioglu, S. T. (2009). Revisiting the tourism-led-growth hypothesis for Turkey using the bounds test and Johansen approach for cointegration. Tourism Management, 30, 1720.

Kim, H. J., Chen, M.-H., \& Jang, S. S. (2006). Tourism Expansion and Economic Development: The Case of Taiwan. Tourism Management, 27, 925-933.

Lee, C.-C., \& Chang, C.-P. (2008). Tourism development and economic growth: A closer look at panels. Tourism Management, 29, 180-192.

Mankiw, N. G. (2009). Brief Principles of Macroeconomics (5th ed.). USA: South- Western Cengage Learning.

McKinnon, D. (1964). Foreign exchange constraint in economic development and efficient aid allocation. Economic Journal (74), 388-409.

Medina-Smith, E. J. (2001). Is The Export-Led Growth Hypothesis Valid for Developing Countries? A Case Study of Costa Rica. Policy Issues in International Trade and Commodities Study Series No.7. New York and Geneva: UNCTAD.

Oh, C.-O. (2005). The Contribution of Tourism Development to Economic Growth in the Kore- 
anEconomy. Tourism Management, 26 (1), 39-44.

Panagiotidis, T., Panagiotou, T., \& Mussoni, M. (2012). Tourism Led Growth: Evidence from Panel Cointegration Tests. Italy: Rimini Centre for Economic Analysis.

Pendit, N. S. (1994). Ilmu Pariwisata: Sebuah Pengantar Perdana (4th ed.). Jakarta: Pradnya Paramita.

Personal, Social, and Humanities Education Section. (2009). Manual on Module I: Introduction to Tourism. Hongkong: The Government of the Hong Kong Special Administrative Region Education Bureau.

Petrakos, G., Arvanitidis, P., \& Pavleas, S. (2007). Determinants of Economic Growth: The Experts' View. DYNREG Working Paper (20).

Ritchie, J. B., \& Crouch, G. I. (2003). The competitive destination: A sustainable tourism perspective. Cabi.

Sakai, M. (2006). Public sector investment in tourism infrastructure. Dalam L. Dwyer, \& P. Forsyth (Penyunt.), International Handbook on the Economics of Tourism. Cheltenham, UK: Edward Elgar.

Samimi, A. J., Sadeghi, S., \& Sadeghi, S. (2011). Tourism and Economic Growth in Developing Countries: P-VAR Approach. Middle-East Journal of Scientific Research , 10 (1), 28-32.

Schwab, K. (2014). The Global Competitiveness Report 2014-2015. Geneva: World Economic Forum.

Sharpley, R. (2006). Travel and Tourism. London: Sage Publications Ltd.

Spurr, R. (2006). Tourism Satellite Accounts. Dalam L. Dwyer, \& P. Forsyth (Penyunt.), International Handbook on the Economics of Tourism. Cheltenham, UK: Edward Elgar.

Theobald, W. F. (2005). The Meaning, Scope, and Measurement of Travel and Tourism. Dalam W. F. Theobald (Penyunt.), Global Tourism (3rd ed.). Burlington, USA: Elsevier Inc.

Todaro, M. P., \& Smith, S. C. (2012). Economic Development (12th ed.). Boston: Pearson Addison Wesley.

Todaro, M. P., \& Smith, S. C. (2000). Pembangunan Ekonomi di Dunia Ketiga. (H. Munandar, Penerj.) Jakarta: Erlangga.

Tribe, J. (2004). The Economics of Recreation, Leisure and Tourism. United Kingdom:Elsevier.

UN Steering Committee on Tourism for Development (SCTD). (2013). United Nations SCTD: Delivering-as-One UN. Dipetik Maret 19, 2015, dari United Nations World Tourism Organization: icr.unwto.org

UN World Tourism Organization. (2014). Tourism Highlights: 2014 Edition. Madrid: UNWTO. United Nations World Tourism Organization. (2013). Sustainable Tourism for Development Guidebook. UN World Tourism Organization.

Weng, C.-C., \& Wang, K.-L. (2004). Scale and Scope Economies of International Tourist Hotels in Taiwan. Tourism Management , 25, 761-769.

World Travel \& Tourism Council. (2012). Benchmarking Travel \& Tourism's economic impact against other sectors. London: WTTC. 